\title{
Teaching Innovation and Entrepreneurship: Impact on Intention and Capability
}

\author{
Antony J. Hodgson and H.F. Machiel Van der Loos \\ Department of Mechanical Engineering, University of British Columbia \\ ahodgson@mech.ubc.ca
}

\begin{abstract}
In last year's conference, we presented a discussion of the relevance of the "Innovation Agenda" for engineering education. In the current paper, we present an overview from the literature of what is understood about the effectiveness of teaching innovation and entrepreneurship in order to prompt discussion about potential implications for engineering curriculum design.
\end{abstract}

Keywords: Innovation, entrepreneurship, curriculum.

\section{INTRODUCTION}

As we discussed last year, in recent years a number of influential reports have been issued discussing the state of innovation in Canada. Some of the most notable of these reports are "Review of Federal Support to Research and Development" (Jenkins Report, 2011), "Innovation Report Card" (Conference Board of Canada, 2012) and the OECD Science, Technology and Innovation Outlook (2012). We argued that in the majority of these reports, engineers are strikingly absent as a formal organized group and that we should think much more seriously about teaching innovation and entrepreneurship as a key component in our curriculum.

\section{LITERATURE REVIEW}

We noted last year that much of the discussion about entrepreneurship and innovation is based in the business world. While there are clearly numerous examples of classes in entrepreneurship offered at various institutions that are either open to engineers or even focused on them, the vast majority of the research about the effectiveness of various instructional approaches is found in the business literature. We therefore begin by presenting some key findings from the more general literature before discussing the more limited literature specifically relevant to educating engineers.

Von Graevenitz et al (2010) note that overall there is little research evaluating the impact of entrepreneurship education and the majority of what exists tends to focus on determining the extent to which taking an entrepreneurship course increases students' intentions to found a company in future; to date, results are mixed, with both positive and neutral-to-negative findings. In their own study of the affective results of a compulsory course in entrepreneurship education in an undergraduate business program in Germany, while they found that intention to found a company decreased following the course, they pointed out that this is consistent with the hypothesis that such a course is useful in helping students determine their own entrepreneurial aptitude. That is, the primary value of the course, aside from educating students in innovation and entrepreneurial processes, may have been to help students better understand whether or not they themselves were well suited for such a pursuit and thereby possibly to have prevented potentially expensive future failures by students who were not wellsuited to launching their own enterprises.

Souitaris et al (2007) focus more specifically on the question of whether entrepreneurship education changes the intention of science and engineering students. In a case-control study involving 250 students in both London and Grenoble, the researchers found that participation in the course did increase both entrepreneurial attitudes and intention. Furthermore, the primary effect on intention was through inspiration, not knowledge, which finding the authors use to argue that "the inspirational part of the programmes has to be designed purposefully ... to change 'hearts and minds'."

\section{DISCUSSION}

We argued last year that engineers should be more explicitly trained in entrepreneurship and innovation processes. This view is supported by Åstebro et al's finding (2012) that startups arising from recentlygraduated science and engineering students are at least ten times more numerous than those arising from faculty members. Through our presentation, we hope to stimulate discussion about how education about innovation and entrepreneurship should be integrated into the modern engineering curriculum.

\section{References}

[1] von Graevenitz G, Harhoff D, Weber R, The effects of entrepreneurship education, J Economic Behavior \& Organization, 76(1), October 2010, pp 90-112

[2] Souitaris V, Zerbinati S, Al-Laham A, Do entrepreneurship programmes raise entrepreneurial intention of science and engineering students? The effect of learning, inspiration and resources, J Bus Venturing, 22(4), July 2007, pp 566-591

[3] Åstebro T, Bazzazian N, Braguinsky S, Startups by recent university graduates and their faculty: Implications for university entrepreneurship policy, Research Policy, 41(4), May 2012, pp 663-677 